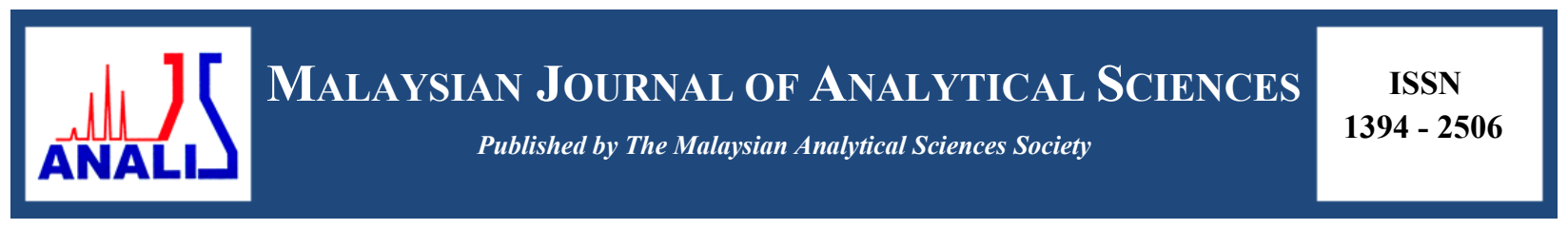

\title{
IN SITU HYDROGENATION OF LIQUID EPOXIDIZED NATURAL RUBBER USING DIIMIDE
}

\author{
(Penghidrogenan In Situ Getah Asli Cecair Terepoksida Menggunakan Diimida) \\ Nur Hanis Adila Azhar ${ }^{1}$, Hamizah Md Rasid ${ }^{1}$, Nur Aidasyakirah Mohd Tahir ${ }^{1}$, Siti Fairus M. Yusoff ${ }^{1,2 *}$ \\ ${ }^{1}$ School of Chemical Science and Food Technology, Faculty of Science and Technology \\ ${ }^{2}$ Polymer Research Center (PORCE), Faculty of Science and Technology \\ Universiti Kebangsaan Malaysia, 43600 UKM Bangi, Selangor, Malaysia \\ *Corresponding author: sitifairus@ukm.edu.my
}

Received: 28 September 2016; Accepted: 6 March 2017

\begin{abstract}
A low-molecular-weight liquid epoxidized natural rubber (LENR) was prepared through photosensitized degradation of epoxidized natural rubber with $50 \mathrm{~mol}$ percent of epoxy content (ENR-50). LENR was modified into hydrogenated liquid epoxidized natural rubber (HLENR) via in situ thermal degradation of arylsulfonyl hydrazide as a hydrogenating agent. The chemical structures of LENR and HLENR were characterized using Fourier transform infrared (FTIR) and ${ }^{1} \mathrm{H}$ nuclear magnetic resonance (NMR) spectroscopies. The thermal behaviour of LENR and HLENR were analysed using thermogravimetric analysis (TGA). The molecular weight and polydispersity index (PDI) of LENR and HLENR were determined using gel permeation chromatography (GPC). The parameter studies on the hydrogenation of LENR were investigated based on the source of diimide, weight ratios of LENR: $p$-toluenesulfonyl hydrazide (TSH), temperature, reaction time and solvent of the reaction. The highest conversion of hydrogenation was achieved at $130{ }^{\circ} \mathrm{C}$ for 4 hours reaction time, with $1: 1$ weight ratio of LENR: TSH using $o-$ xylene as a solvent.
\end{abstract}

Keywords: hydrogenation, liquid natural rubber, epoxidized, hydroxylated

\begin{abstract}
Abstrak
Getah asli cecair terepoksida (LENR) dihasilkan melalui penguraian fotopemeka yang dijalankan ke atas getah asli terepoksida yang mempunyai 50 mol\% kandungan epoksi (ENR-50). LENR dihidrogenkan kepada LENR terhidrogen (HLENR) melalui penguraian terma in situ dengan menggunakan agen penghidrogenan iaitu arilsulfonil hidrazida. Struktur kimia LENR dan HLENR dicirikan menggunakan spektroskopi inframerah transformasi Fourier (FTIR) dan resonans magnet nukleus ${ }^{1}$ H. Sifat terma LENR dan HLENR dikaji menggunakan analisis termogravimetri (TGA). Berat molekul dan indeks kepoliserakan (PDI) dikaji menggunakan kromatografi penelapan gel (GPC). Kajian mengenai penghidrogenan LENR dikaji berdasarkan beberapa parameter tindak balas seperti sumber diimida, nisbah berat LENR: $p$-toluenasulfonil hidrazida (TSH), suhu, masa dan pelarut tindak balas. Penukaran penghidrogenan yang tertinggi diperolehi apabila tindak balas dijalankan pada suhu $130{ }^{\circ} \mathrm{C}$ selama 4 jam, dengan nisbah berat LENR:TSH sebanyak 1:1 serta menggunakan $o$-xilena sebagai pelarut.
\end{abstract}

Kata kunci: penghidrogenan, getah asli cecair, terepoksida, terhidroksil

\section{Introduction}

Natural rubber (NR) produced from Hevea brasiliensis trees is a crucial raw material for the production of industrial products such as tyres, gloves, adhesives, sealants, medical devices and consumer products [1-3]. NR had been used in various fields of applications due to its high elasticity and flexibility, resilience, abrasion resistance, efficient heat 
dispersion, impact resistance and tear strength $[4,5]$. However, NR deteriorates against ozone, sunlight, and weathering due to the unsaturated in its polymeric chains $[4,6]$. Thus, chemical modifications of NR are very important in order to enhance the chemical, physical and mechanical properties of NR.

Previously, there are many chemical modifications that had been done to NR such as, hydrogenation, epoxidation, halogenation, grafting, metathesis and cyclization [1]. Among these modifications, hydrogenation of NR is significance to improve the properties in terms of its thermal stability, weather resistance and oxidative [7]. There are two types of hydrogenation that had been done to NR, which are catalytic and non-catalytic. Catalytic hydrogenation requires high pressure autoclave and the presence of transition metal catalyst systems such as nickel, titanium, rhodium, ruthenium or palladium [ $8-11]$. On the other hand, non-catalytic hydrogenation method is more convenient because it only requires a simple apparatus preparation at atmospheric pressure and employed diimide intermediate from thermal decomposition of arylsulfonyl hydrazide [12]. Mahittikul et al. reported an in situ hydrogenated natural rubber latex via thermolysis of $p$-toluenesulfonyl hydrazide (TSH) [13].

Epoxidized natural rubber (ENR) is a chemically modified form of NR, having epoxy functional group and also showed slightly similar drawbacks as NR due to its remaining unsaturated double bonds in polymeric backbones. Hence, hydrogenation of ENR will overcome the drawbacks by saturating the remaining double bonds and ring opened the epoxy groups into hydroxyl groups. Research on the hydrogenation of ENR conducted in latex form requires a deproteinization process to remove the protein in the rubber [11]. Although, chemical reactions conducted in latex form often encountered with problems of latex stability, uneven particle size distribution and contamination due to non-rubber components of natural rubber latex [14]. To overcome the problems encountered by latex, liquid form of ENR is the best solution. The liquid form of ENR which is liquid epoxidized natural rubber (LENR), a partially depolymerized ENR can be produced via mechanical milling, chemical degradation initiated by potassium peroxodisulfate and photooxidation initiated by ultraviolet irradiation [15].

In the present work, we made an attempt to hydrogenate liquid epoxidized natural rubber through the thermal degradation of TSH. The diimide $\left(\mathrm{N}_{2} \mathrm{H}_{2}\right)$ generated from thermolysis of TSH gives hydrogen molecules $\left(\mathrm{H}_{2}\right)$ to the $\mathrm{C}=\mathrm{C}$ and $\mathrm{C}-\mathrm{O}-\mathrm{C}$ of the LENR (Scheme 1) $[13,16,17]$. We also optimize the effect of TSH concentration, temperature, solvent and reaction time. The analysis of the hydrogenated products have been performed using FTIR, ${ }^{1} \mathrm{H}$ NMR, TGA and GPC.

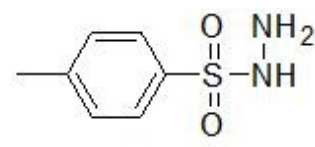

p-toluenesulfonyl hydrazide

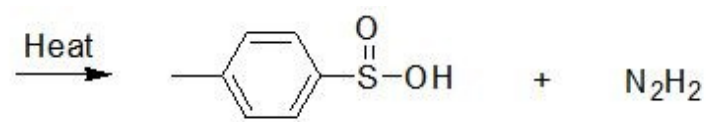

p-toluenesulfonic acid

Diimide

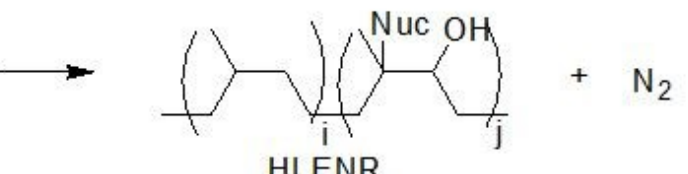

HLENR
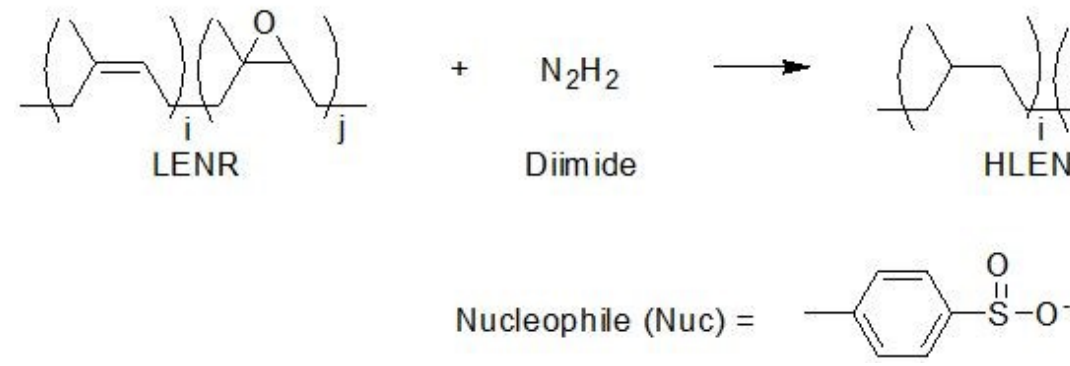

Scheme 1. Hydrogenation of LENR using TSH 


\section{Materials}

\section{Materials and Methods}

Epoxidized natural rubber-50 (ENR-50) was supplied from Malaysian Rubber Board. Toluene, $o$-xylene, hexane and methanol were supplied by R\&M Chemicals. Methylene blue, rose Bengal, $p$-toluenesulfonyl hydrazide (TSH) and 2,4,6-trimethylbenzenesulfonyl hydrazide (MSH) were purchased from Sigma Aldrich.

\section{Synthesis of LENR}

LENR was prepared by photosensitized degradation of ENR-50 [18]. $1 \mathrm{~kg}$ of ENR-50 was cut into smaller cube and soaked in $2 \mathrm{~L}$ of toluene overnight. Methylene blue $(0.10 \mathrm{~g})$ and Rose Bengal $(0.15 \mathrm{~g})$ were dissolved in methanol before added into rubber mixture. The mixture was stirred continuously using a mechanical stirrer in the presence of visible light at $70{ }^{\circ} \mathrm{C}$ for 10 to 14 days. The mixture was centrifuged to separate the gel formation.

\section{Hydrogenation of LENR}

TSH was used as a diimide source in the hydrogenation reaction. Different amounts of TSH were added to a fixed volume of LENR solution at TSH/LENR weight ratios of 1:1 to 3:1 to determine the effect of TSH concentration on the percentage of hydrogenation. Each mixture was heated to temperature ranging from $90{ }^{\circ} \mathrm{C}$ until $150{ }^{\circ} \mathrm{C}$ and stirred for 1-5 hours to study the effect of reaction time on the percentage of hydrogenation. The products were filtered and coagulated with hexane to remove the residual TSH. Finally, it was dried in a vacuum oven to remove any remaining solvent. In this work, we also studied the effect of solvent by using $o$-xylene and toluene on the percentage of hydrogenation LENR.

\section{Characterization}

Attenuated total reflectance-Fourier transform infrared (ATR-FTIR) spectroscopy (Perkin Elmer) was used to determine any changes in the functional groups that might have been induced by the hydrogenation reaction. The samples were analysed in the wavenumber range of $4000-600 \mathrm{~cm}^{-1}$. NMR spectroscopy was used to examine the microstructure of the product. Samples were dissolved in deuterated chloroform $\left(\mathrm{CDCl}_{3}\right)$ for measurements with the Fourier Transform Nuclear Magnetic Resonance 400MHz Cryoprobe (FT-NMR 400MHz Cryo). Integration of signals from proton NMR ( ${ }^{1} \mathrm{H}$ NMR) was used to estimate the percentage of conversion of the hydrogenation, content of the epoxy group, content of the residual double bonds and content of the hydroxyl group of HLENR as shown in equation $1-4$ below:

$$
\begin{aligned}
& \mathrm{W}_{\text {conversion }}[\mathrm{mol} \%]=\frac{\mathrm{I}_{1.25} / 2}{\mathrm{I}_{125} / 2+\mathrm{I}_{271}+\mathrm{I}_{3.35}+\mathrm{I}_{5.14}} \times 100 \\
& \mathrm{X}_{\text {epoxy }}[\mathrm{mol} \%]=\frac{\mathrm{I}_{2.71}}{\mathrm{I}_{1.25} / 2+\mathrm{I}_{2.71}+\mathrm{I}_{3.35}+\mathrm{I}_{5.14}} \times 100 \\
& \mathrm{Y}_{\text {double bond }}[\mathrm{mol} \%]=\frac{\mathrm{I}_{3.35}}{\mathrm{I}_{2.25} / 2+\mathrm{I}_{2.71}+\mathrm{I}_{3.35}+\mathrm{I}_{5.14}} \times 100 \\
& \mathrm{Z}_{\text {hydroxyl }}[\mathrm{mol} \%]=\frac{\mathrm{I}_{1.25} / 2+\mathrm{I}_{2.71}+\mathrm{I}_{3.35}+\mathrm{I}_{5.14}}{\mathrm{I}_{1.25} / 2+\mathrm{I}_{2.71}+\mathrm{I}_{3.35}+\mathrm{I}_{5.14}} \times 100
\end{aligned}
$$

where $I$ is the integration at chemical shifts $1.25,2.71,3.35$ and $5.14 \mathrm{ppm}$ that correspond to methylene of hydrogenated isoprene units, epoxy methine of epoxidized-cis-1,4-isoprene units, hydroxylated methine and olefinic methine of unsaturated cis-1,4-isoprene units, respectively, in ${ }^{1} \mathrm{H}$ NMR spectrum [11].

Thermogravimetric analysis (TGA) and differential thermal analysis (DTA) were performed on TGA/SDTA $851^{\mathrm{e}}$, Mettler Toledo. Gel permeation chromatography (GPC) was employed to determine the molecular weight $\left(\mathrm{M}_{\mathrm{w}}\right)$ and polydispersity index (PDI) of LENR and HLENR (Waters 1515 Isocratic HPLC Pump equipped with a Waters 2414 Refractive Index detector, Waters Corporation, USA).

\section{Results and Discussion}

Hydrogenated liquid epoxidized natural rubber (HLENR) was produced via non-catalytic hydrogenation of LENR using diimide intermediate from arylsulfonyl hydrazide such as $p$-toluenesulfonyl hydrazide (TSH) and 2,4,6trimethylbenzenesulfonyl hydrazide (MSH). 


\section{Microstructure of LENR and HLENR}

Figure 1 depicts the FTIR spectra of LENR and HLENR. The main features of LENR appears at 1251 and $870 \mathrm{~cm}^{-1}$ are attributed to the symmetric and asymmetric stretching of the epoxide ring, respectively. The absorption at 1664 and $828 \mathrm{~cm}^{-1}$ in LENR spectrum correspond to $\mathrm{C}=\mathrm{C}$ stretching and olefinic $\mathrm{C}-\mathrm{H}$ bending, respectively. Both LENR and HLENR spectra show broad absorption bands at 3600-3100 $\mathrm{cm}^{-1}$ due to O-H stretching, and the intensities of the absorption bands for HLENR are intense than LENR [19]. The increment of HLENR intensity at 3600-3100 $\mathrm{cm}^{-1}$ arised due to the ring opening of epoxy groups into hydroxyl groups.

${ }^{1} \mathrm{H}$ NMR spectra of LENR and HLENR were shown in Figure 2. In LENR spectrum, six major signals appeared at $1.30,1.68,2.10,2.20,2.71$ and $5.14 \mathrm{ppm}$ were assigned to methyl of unsaturated cis-1,4-isoprene units $(b)$, methyl of epoxidized-cis-1,4-isoprene units (e), methylene of cis-1,4-isoprene units (c), methylene of epoxidized-cis-1,4isoprene units $(f)$, epoxy methine $(d)$ and olefinic methine $(a)$, respectively. HLENR spectrum showed the appearance of hydrogenated methylene $\left(a^{\prime}\right)$ hydroxylated methine $(h)$ and hydroxyl proton $(i)$ at chemical shifts $1.25,3.35$ and $3.90 \mathrm{ppm}$, respectively. The signals appeared at 2.30-2.50 ppm on HLENR spectrum correspond to benzylic protons of the remaining TSH and the nucleophile $\left(\mathrm{CH}_{3} \mathrm{C}_{6} \mathrm{H}_{5} \mathrm{SO}_{2}^{-}\right)[12,17,20]$.

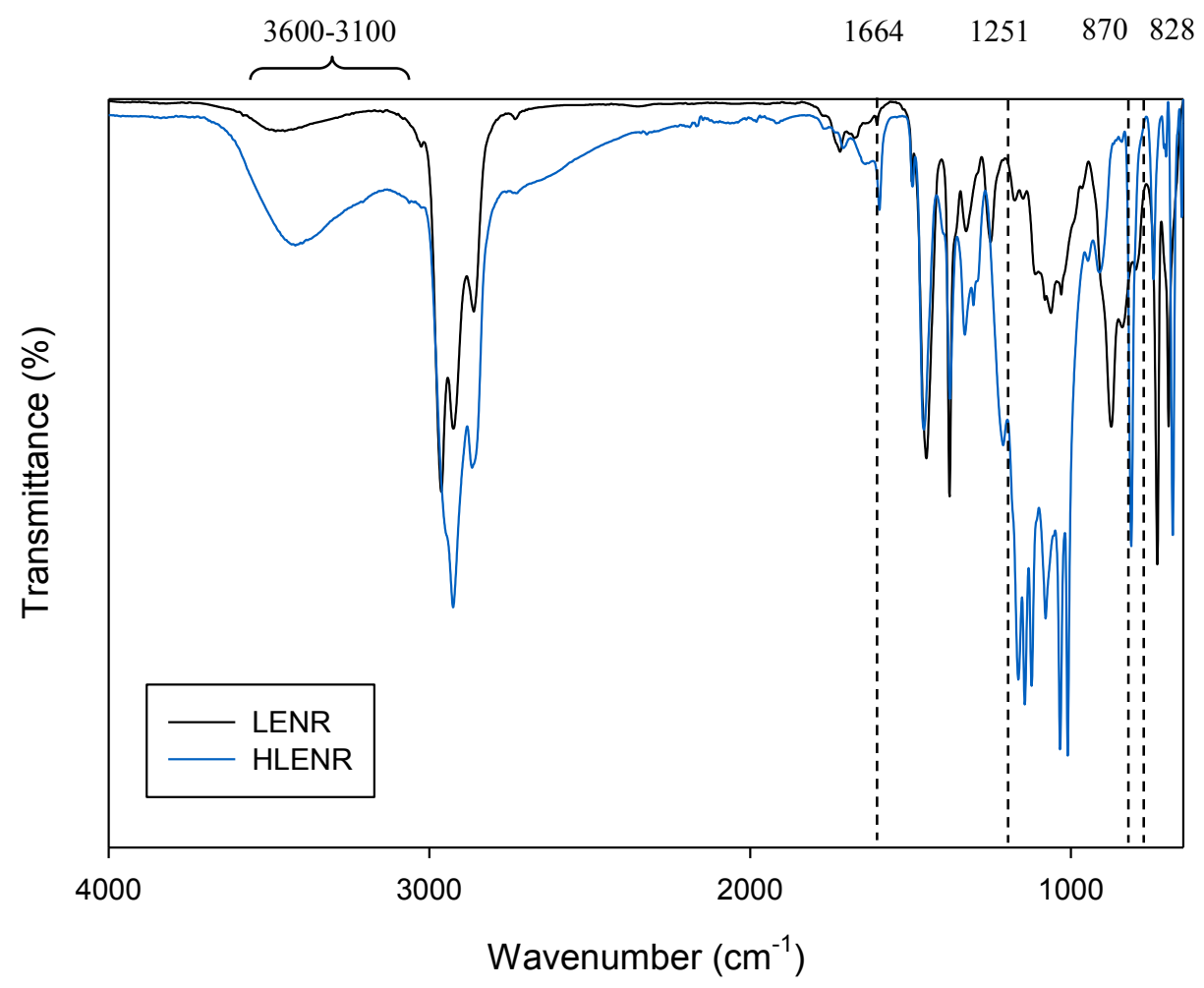

Figure 1. FTIR spectra of LENR and HLENR 


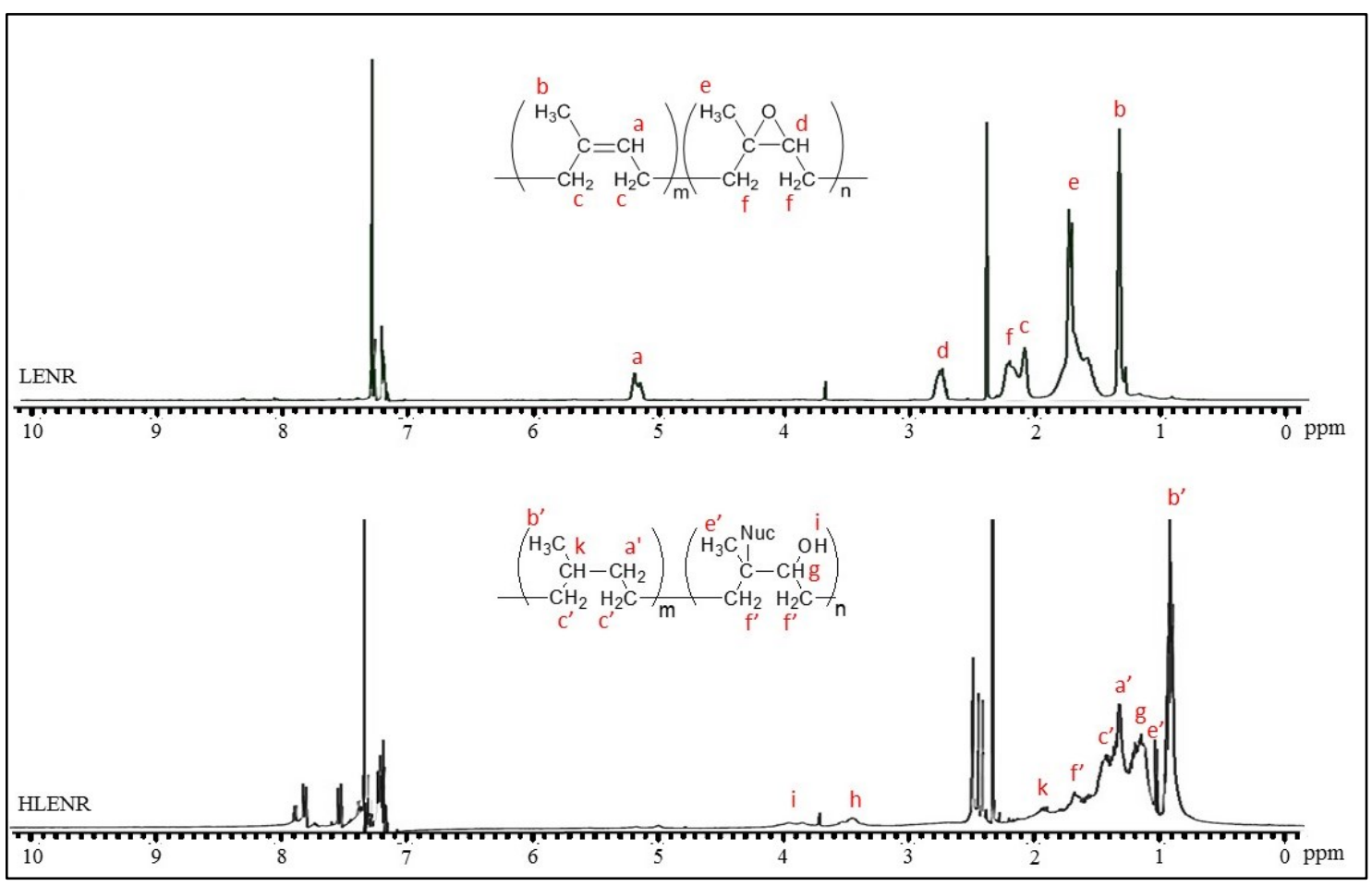

Figure 2. ${ }^{1} \mathrm{H}$ NMR spectra of LENR and HLENR

\section{Parameter Studies on Hydrogenation of LENR: Effect of diimide source}

p-toluenesulfonyl hydrazide (TSH) and 2,4,6-trimethylbenzenesulfonyl hydrazide (MSH) had been study to produce diimide for the non-catalytic hydrogenation of LENR (Table 1). TSH showed a higher conversion of hydrogenation which is $90.29 \%$. The hydrogenation of LENR using MSH produced more hydroxyl content caused by the stronger nucleophilic attack in the epoxide ring compare to TSH. The content of epoxy group and residual double bonds decreased as the conversion of hydrogenation increased. However, the content of hydroxyl for hydrogenation LENR using MSH was higher compared to TSH because, MSH was quite unstable to undergo hydrogenation.

Table 1. Effect of diimide source on hydrogenation of LENR

\begin{tabular}{llcccc}
\hline Experiment & $\begin{array}{l}\text { Diimide } \\
\text { Source }\end{array}$ & $\begin{array}{c}\text { Conversion of } \\
\text { Hydrogenation } \\
\text { (mol\%) }\end{array}$ & $\begin{array}{c}\text { Content of } \\
\text { Epoxy Group } \\
\text { (mol \%) }\end{array}$ & $\begin{array}{c}\text { Content of } \\
\text { Residual Double } \\
\text { Bonds (mol \%) }\end{array}$ & $\begin{array}{c}\text { Content of } \\
\text { Hydroxyl Group } \\
\text { (mol \%) }\end{array}$ \\
\hline 1 & TSH & 90.29 & 0.81 & 0.45 & 8.46 \\
2 & MSH & 40.80 & 7.94 & 3.80 & 47.47 \\
\hline
\end{tabular}

Condition: weight ratio of TSH: $\mathrm{LENR}=1: 1$, temperature $=130^{\circ} \mathrm{C}$, reaction time $=4$ hours, solvent $=o$-xylene

\section{Effect of LENR: TSH weight ratio}

The weight ratio of LENR: TSH was varied for 1:1, 1:2 and 1:3. Table 2 showed the increase in the amount of TSH, resulted to reduce the conversion of hydrogenation of LENR. Higher amount of TSH was expected to undergo side reaction which interrupt the hydrogenation of LENR and reduced the hydroxyl content. The epoxy content increased as the conversion of hydrogenation decreased. 
Table 2. Effect of LENR: TSH weight ratio on hydrogenation of LENR

\begin{tabular}{llcccc}
\hline Experiment & $\begin{array}{c}\text { Weight Ratio of } \\
\text { LENR:TSH }\end{array}$ & $\begin{array}{c}\text { Conversion of } \\
\text { Hydrogenation } \\
\text { (mol\%) }\end{array}$ & $\begin{array}{c}\text { Content of } \\
\text { Epoxy Group } \\
\text { (mol\%) }\end{array}$ & $\begin{array}{c}\text { Content of } \\
\text { Residual } \\
\text { Double Bonds } \\
\text { (mol\%) }\end{array}$ & $\begin{array}{c}\text { Content of } \\
\text { Hydroxyl } \\
\text { Group } \\
\text { (mol\%) }\end{array}$ \\
\hline 3 & $1: 1$ & 90.29 & 0.81 & 0.45 & 8.46 \\
4 & $1: 2$ & 56.27 & 40.00 & 0.95 & 2.77 \\
5 & $1: 3$ & 56.27 & 42.16 & 0.16 & 1.40 \\
\hline
\end{tabular}

Condition: temperature $=130^{\circ} \mathrm{C}$, reaction time $=4$ hours, solvent $=o$-xylene

\section{Effect of temperature}

The effect of temperature was investigated from $90{ }^{\circ} \mathrm{C}$ until $150{ }^{\circ} \mathrm{C}$ (Table 3). From $90{ }^{\circ} \mathrm{C}$ until $130{ }^{\circ} \mathrm{C}$, the conversion of hydrogenation gradually increase to the highest conversion of hydrogenation. TSH solubility with $o$ xylene increased with the increasing temperature because rate decomposition of TSH increased. However, when the temperature was increased to $150{ }^{\circ} \mathrm{C}$, the conversion of hydrogenation slightly dropped due to the occurrence of unduly wasteful side reaction [13]. The content of epoxy group and residual double bonds decreased while content of hydroxyl increased as the conversion of hydrogenation increased.

Table 3. Effect of temperature on hydrogenation of LENR

\begin{tabular}{llcccc}
\hline Experiment & $\begin{array}{l}\text { Temperature } \\
\left({ }^{\circ} \mathbf{C}\right)\end{array}$ & $\begin{array}{c}\text { Conversion of } \\
\text { Hydrogenation } \\
(\mathbf{m o l} \%)\end{array}$ & $\begin{array}{c}\text { Content of } \\
\text { Epoxy Group } \\
(\mathbf{m o l})\end{array}$ & $\begin{array}{c}\text { Content of } \\
\text { Residual Double } \\
\text { Bonds (mol\%) }\end{array}$ & $\begin{array}{c}\text { Content of } \\
\text { Hydroxyl } \\
\text { Group (mol\%) }\end{array}$ \\
\hline 6 & 90 & 46.78 & 37.27 & 11.42 & 4.53 \\
7 & 110 & 53.44 & 35.74 & 5.49 & 5.33 \\
8 & 130 & 90.29 & 0.81 & 0.45 & 8.46 \\
9 & 150 & 86.6 & 0.18 & 0.77 & 12.45 \\
\hline
\end{tabular}

Condition: weight ratio of TSH: $\mathrm{LENR}=1: 1$, reaction time $=4$ hours, solvent $=o$-xylene

\section{Effect of reaction time}

Table 4 showed the increasing trend of reaction time has increased the conversion of hydrogenation. At the reaction of 5 hours, the conversion of hydrogenation almost the same with the conversion of hydrogenation for 4 hours because the reaction already completed at 4 hours reaction time. The content of epoxy group and residual double bonds decreased while content of hydroxyl increased when the conversion of hydrogenation increased.

Table 4. Effect of reaction time on hydrogenation of LENR

\begin{tabular}{llcccc}
\hline Experiment & $\begin{array}{l}\text { Reaction } \\
\text { Time } \\
\text { (hours) }\end{array}$ & $\begin{array}{c}\text { Conversion of } \\
\text { Hydrogenation } \\
\text { (mol\%) }\end{array}$ & $\begin{array}{c}\text { Content of } \\
\text { Epoxy Group } \\
\text { (mol\%) }\end{array}$ & $\begin{array}{c}\text { Content of } \\
\text { Residual Double } \\
\text { Bonds (mol\%) }\end{array}$ & $\begin{array}{c}\text { Content of } \\
\text { Hydroxyl Group } \\
\text { (mol\%) }\end{array}$ \\
\hline 10 & 1 & 33.71 & 56.78 & 5.87 & 3.64 \\
11 & 2 & 53.94 & 42.95 & 1.26 & 1.85 \\
12 & 3 & 78.99 & 15.75 & 2.15 & 8.70 \\
13 & 4 & 90.29 & 0.81 & 0.45 & 8.46 \\
14 & 5 & 90.11 & 0.01 & 1.29 & 8.59 \\
\hline
\end{tabular}

Condition: weight ratio of TSH: $\mathrm{LENR}=1: 1$, temperature $=130^{\circ} \mathrm{C}$, solvent $=o$-xylene 


\section{Effect of solvent}

There were two types of solvent had been studied on the hydrogenation of LENR. Based from Table 5, $o$-xylene resulted in higher conversion of hydrogenation due to $o$-xylene is more likely to dissolve TSH and easily produced diimide. However, the hydrogenation of LENR using toluene produced a lower conversion of hydrogenation but higher in hydroxyl group.

Table 5. Effect of solvent on hydrogenation of LENR

\begin{tabular}{llcccc}
\hline Experiment & Solvent & $\begin{array}{c}\text { Conversion of } \\
\text { Hydrogenation } \\
(\mathbf{m o l \% )}\end{array}$ & $\begin{array}{c}\text { Content of } \\
\text { Epoxy Group } \\
\text { (mol\%) }\end{array}$ & $\begin{array}{c}\text { Content of Residual } \\
\text { Double Bonds } \\
\text { (mol\%) }\end{array}$ & $\begin{array}{c}\text { Content of } \\
\text { Hydroxyl Group } \\
\text { (mol\%) }\end{array}$ \\
\hline 15 & Toluene & 46.45 & $\sim 0$ & 2.24 & 51.31 \\
16 & $o$-xylene & 90.29 & 0.81 & 0.45 & 8.46 \\
\hline
\end{tabular}

Condition: weight ratio of TSH: $\mathrm{LENR}=1: 1$, temperature $=130^{\circ} \mathrm{C}$, reaction time $=4$ hours

\section{Thermal analysis of LENR and LNR-OH}

TGA and DTG thermograms of LENR and HLENR were shown on Figure 3 and 4, respectively. LENR and HLENR thermograms showed multi step changes. The first step changes $\left(30^{\circ} \mathrm{C}-310^{\circ} \mathrm{C}\right)$ of LENR and HLENR were due to the loss of solvent, moisture and low-molecular-weight oligomers [21]. After $310{ }^{\circ} \mathrm{C}$ to $400{ }^{\circ} \mathrm{C}$, the weight loss were due to the unstable intermediates in hydrogenation of LENR. The Figure 4 clearly showed the maximum degradation temperature of LENR and HLENR at $413{ }^{\circ} \mathrm{C}$ and $445{ }^{\circ} \mathrm{C}$, respectively. The maximum degradation temperature of HLENR showed a higher temperature compared to LENR because of the hydrogenation reaction had proven to saturate the unsaturated part of LENR.

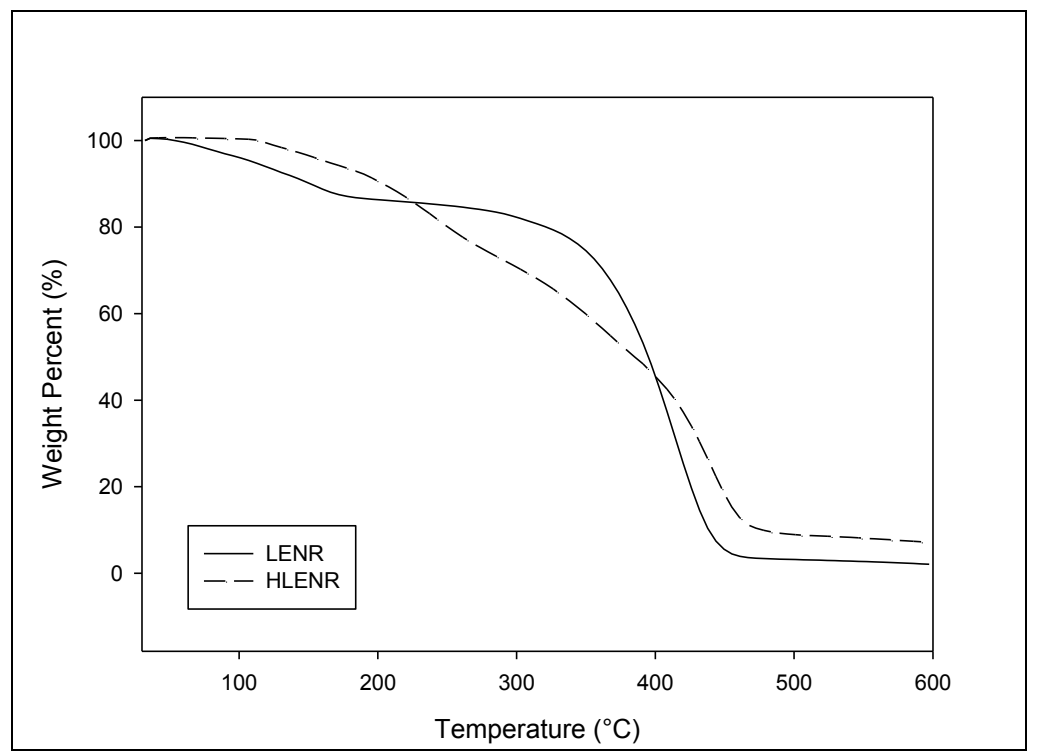

Figure 3. TGA thermograms of LENR and HLENR 


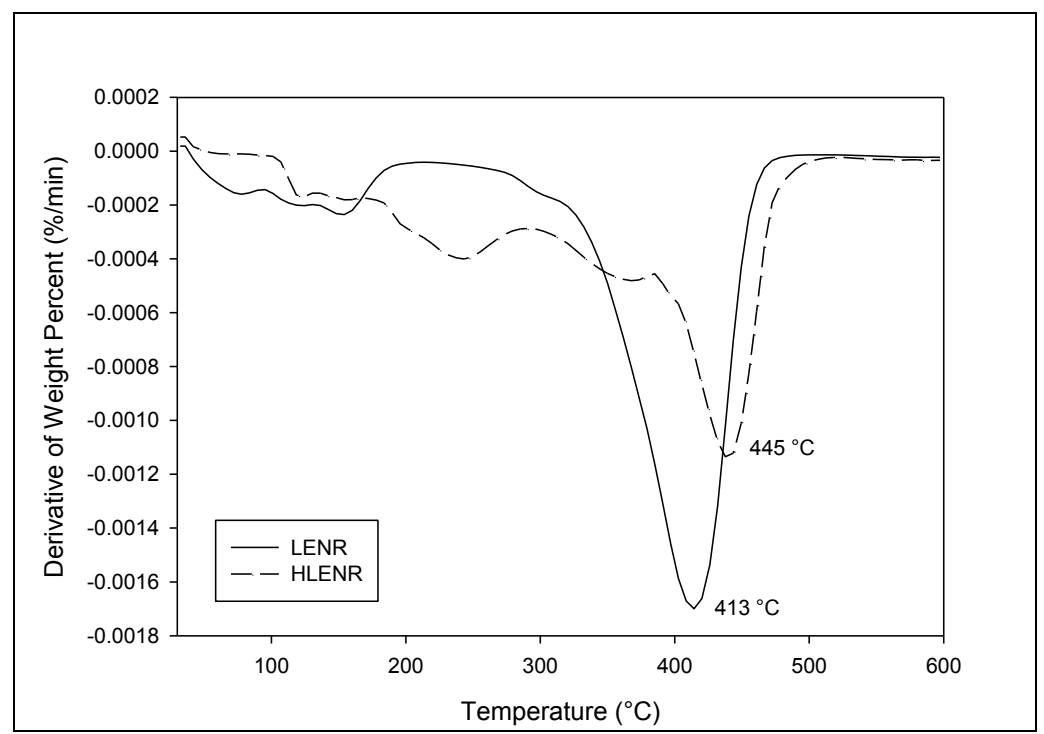

Figure 4. DTG thermograms of LENR and HLENR

\section{Molecular Weight of LENR and LNR-OH}

Table 6 showed the number average molecular weight $\left(\mathrm{M}_{n}\right)$, weight average molecular weight $\left(\mathrm{M}_{w}\right)$ and polydispersity index (PDI) of LENR and HLENR. $\mathrm{M}_{w}$ of LENR and HLENR were reduced from $47900 \mathrm{~g} / \mathrm{mol}$ to $17000 \mathrm{~g} / \mathrm{mol}$ due to the high reaction temperature in the hydrogenation of LENR. The high reaction temperature depolymerized the polymeric chains of HLENR.

Table 6. Molecular weight of LENR and HLENR

\begin{tabular}{lccc}
\hline Sample & $\mathbf{M}_{\boldsymbol{n}}$ & $\mathbf{M}_{\boldsymbol{w}}$ & PDI \\
\hline LENR & 18200 & 47900 & 2.63 \\
HLENR & 4600 & 17000 & 3.69 \\
\hline
\end{tabular}

\section{Conclusion}

Non-catalytic hydrogenation of LENR using diimide was efficiently conducted to produce hydrogenated rubber containing hydroxyl group. The optimum reaction condition was achieved using TSH as diimide source with 1:1 of LENR: TSH weight ratio at $130{ }^{\circ} \mathrm{C}$ for 4 hours of reaction time using $o$-xylene as solvent.

\section{Acknowledgement}

The authors would like to acknowledge Universiti Kebangsaan Malaysia (UKM) for the research grants (GUP2017-004 and FRGS/1/2016/STG01/UKM/02/4), Ministry of Science, Technology and Innovation (MOSTI), Malaysia for research grant (03-01-02-SF1207) and Centre for Research and Instrumentation (CRIM) at UKM for their facilities.

\section{References}

1. Wongthong, P., Nakason, C., Pan, Q., Rempel, G. L. and Kiatkamjornwong, S. (2013). Modification of deproteinized natural rubber via grafting polymerization with maleic anhydride. European Polymer Journal, 49(12): 4035 - 4046.

2. Mooibroek, H. and Cornish, K. (2000). Alternative sources of natural rubber. Applied Microbiology and Biotechnology, 53(4): $355-365$. 
3. Hayashi, Y. (2009). Production of natural rubber from Para rubber tree. Plant Biotechnology, 26(1): 67 -70.

4. Kongparakul, S., Ng, F. T. T. and Rempel, G. L. (2011). Metathesis hydrogenation of natural rubber latex. Applied Catalysis A: General, 405(1-2): 129 - 136.

5. Ayutthaya, W. D. N. and Poompradub, S. (2014). Thermal and mechanical properties of poly(lactic acid)/natural rubber blend using epoxidized natural rubber and poly(methyl methacrylate) as cocompatibilizers. Macromolecular Research, 22(7): 686- 692.

6. Pisuttisap, A., Hinchiranan, N., Rempel, G. L. and Prasassarakich, P. (2013). ABS modified with hydrogenated polystyrene-grafted-natural rubber. Journal of Applied Polymer Science, 129(1): 94 - 104.

7. Nghia, P. T., Onoe, H., Yamamoto, Y. and Kawahara, S. (2008). Hydrogenation of natural rubber having epoxy group. Colloid and Polymer Science, 286(8-9): 993 - 998.

8. Samran, J., Phinyocheep, P., Daniel, P., Derouet, D. and Buzaré, J. Y. (2004). Raman spectroscopic study of non-catalytic hydrogenation of unsaturated rubbers. Journal of Raman Spectroscopy, 35(12): 1073 -1080.

9. Bhattacharjee, S., Bhowmick, A. K. and Avasthi, B. N. (1993). Hydrogenation of epoxidized natural rubber in the presence of palladium acetate catalyst. Polymer, 34(24): $5168-5173$.

10. Sanjoy Roy, S. and Bhattacharjee, B. R. G. (1993). Hydrogenation of epoxidized natural rubber. Journal of Applied Polymer Science, 49: 375 - 380.

11. Ha, N. T., Shiobara, K., Yamamoto, Y., Fukuhara, L., Nghia, P. T. and Kawahara, S. (2015). Preparation and characterization of hydrogenated natural rubber with hydroxyl groups. Polymers for Advanced Technologies, 26(12): $1504-1511$.

12. Rasid, H. M., Azhar, N. H. A., Jamaluddin, N. and Yusoff, S. F. M. (2016). Mild approach for non-catalytic hydrogenation of liquid natural rubber using 2,4,6-trimethylbenzenesulfonyl hydrazide as the diimide source. Bulletin of the Korean Chemical Society, 37(6): 797 - 801.

13. Mahittikul, A., Prasassarakich, P. and Rempel, G. L. (2007). Noncatalytic hydrogenation of natural rubber latex. Journal of Applied Polymer Science, 103(5): 2885 - 2895.

14. Heijden, J. v. d. (2002). Natuurrubber $28-4^{\text {th }}$ quarter 2002. Rubber-Stichting: pp $1-20$.

15. Rooshenass, P., Yahya, R. and Gan, S. N. (2016). Comparison of three different degradation methods to produce liquid epoxidized natural rubber. Rubber Chemistry and Technology, 89(1): 177 - 198.

16. Hunig, S., Muller, H. R. and Thier, W. (1965). The chemistry of diamine. Angewandte Chemie International Edition, 4(4): 271 - 380.

17. Wade, L. G. (2003). Organic chemistry (5 $5^{\text {th }}$ Edition). Prentice Hall, New Jersey.

18. Abdullah, I. (1996). Process for manufacturing liquid natural rubber (LNR). Malaysian Patent, MY-108852-A.

19. Jorge, R. M., Lopes, L., Benzi, M. R., Ferreira, M. T., Gomes, A. S. and Nunes, R. C. R. (2010). Thiol addition to epoxidized natural rubber: Effect on the tensile and thermal properties. International Journal of Polymeric Materials, 59(5): 330 - 341.

20. Azhar, N. H. A., Jamaluddin, N., Md Rasid, H., Mohd Yusof, M. J. and Yusoff, S. F. M. (2015). Studies on hydrogenation of liquid natural rubber using diimide. International Journal of Polymer Science, 2015: 1-6.

21. Mahmood, W. A. K. and Azarian, M. H. (2015). Thermal, surface, nanomechanical and electrical properties of epoxidized natural rubber (ENR-50)/ polyaniline composite films. Current Applied Physics, 15(5): 599 - 607. 